\title{
Insufficient hypothalamic angiotensin-converting enzyme 2 is associated with hypertension in SHR rats
}

\author{
Kun Wang ${ }^{1}$, Yuanyuan $X u^{1}$, Weiwei Yang ${ }^{1}$, Yuanshu Zhang ${ }^{1}$ \\ ${ }^{1}$ College of Veterinary Medicine, Nanjing Agricultural University, Nanjing 210095, China \\ Correspondence to: Yuanshu Zhang, email: zhangyuanshu@njau.edu.cn \\ Keywords: SHR, ACE2, hypothalamus, pituitary, hypertension \\ Received: April 25, $2016 \quad$ Accepted: January 03, $2017 \quad$ Published: February 24, 2017
}

\section{ABSTRACT}

Angiotensin-Converting Enzyme 2 (ACE2) is a key enzyme in the reninangiotensin system (RAS), which is implicated in the pathogenesis of hypertension and other cardiovascular diseases. In this study we investigated the expression of ACE2 in the hypothalamus and pituitary tissues and its relationship to hypertension by comparing them in male WKY and SHR rats. We observed that the plasma levels of corticotrophin releasing hormone (CRH), adrenocorticotropic hormone (ACTH) and aldosterone (ALD) were all lower in SHR than WKY rats $(P<0.05)$, whereas plasma angiotensin II (AngII) levels were higher in SHR rats $(P<0.05)$. Levels of ACE mRNA and protein were higher in the hypothalamus of SHR than WKY rats $(P<0.05)$. By contrast, hypothalamic expression of ACE2 protein was lower in SHR rats $(P<0.05)$, despite comparable mRNA levels in SHR and WKY rats. There were no differences in the expression levels of ACE, ACE2, AT1 or Mas mRNA in the pituitaries of SHR and WKY rats $(P>0.05)$. These results suggest that insufficiency of hypothalamic ACE 2 is associated with hypertension in SHR rats.

\section{INTRODUCTION}

The role of the renin-angiotensin system (RAS) in the pathogenesis of hypertension and other cardiovascular diseases is widely acknowledged [1]. However, the traditional view that Ang II is the sole key effector peptide of the RAS has been questioned by the subsequent discovery of angiotensin-converting enzyme 2 (ACE2) $[2,3]$ and the growing evidence for a physiological role for Angiotensin-(1-7) [4]. Angiotensin-converting enzyme 2 (ACE2) is a homologue of the angiotensin-converting enzyme (ACE) that catalyzes Ang II into Ang-(1-7). Angiotensin-(1-7) is a peptide that binds to the G-proteincoupled receptor Mas (MasR) and initiates vasodilator and anti-proliferative responses [5]. Also, Ang-(1-7) antagonizes the cardiovascular actions of Ang II [6].

RAS is associated with hypertension in the spontaneously hypertensive rats (SHR) [7]. Cardiac ACE2 was suppressed and ACE upregulated in the SHR compared to WKY rats [8]. Moreover, it was implicated in pro-inflammatory cytokines (PICs) such as tumor necrosis factor (TNF)-a, interleukin (IL)-6, and IL-1b both centrally and in the periphery $[9,10]$.
The RAS system is expressed in many tissues such as pancreas, heart, liver, lungs, adipose tissue and brain and regulates blood pressure and fibrosis in these tissues [11, 12]. There is evidence that the brain RAS has a critical role in regulating blood pressure, water balance and endocrine secretion. Recent studies have demonstrated ACE2 mRNA in the rat medulla oblongata and detected ACE2 activity in the mouse brain $[13,14]$. Lin and co-workers used in situ hybridization to measure ACE2 mRNA in the brainstem and demonstrated a relationship between the Angiotensin type 1a receptor (AT1a) and ACE2 expression [15]. ACE2 has also been implicated in attenuating hypertension in the brain and the hypothalamus $[16,17]$. However, the role of ACE2 in the WKY hypothalamic-pituitary axis has not been investigated. Since the levels of angiotensin (1-7) were higher in the hypophyseal portal plasma compared to matched jugular plasma samples, a potential role for ACE2 within the hypothalamic-pituitary axis was postulated. Therefore, we analyzed the ACE2 mRNA and protein levels in the WKY and SHR rat HPA along with the plasma levels of CRH, ACTH, ALD and AngII to understand the link between ACE2 expression in the HPA and hypertension. 


\section{RESULTS}

\section{Systolic blood pressure, diastolic blood pressure,} heart rate, and body weight

Systolic blood pressure, Diastolic blood pressure, Heart rate, and Body weight were shown in Figure 1. Compared with WKY, the systolic blood pressure (SBP) and diastolic blood pressure (SDP) of SHR were increased significantly. However, the resting heart rate and body weights did not differ between two groups.

\section{Plasma CRH, ACTH, ALD and Ang II levels}

Levels of CRH, ACTH, ALD and AngII in plasma were shown in Figure 2. Unpaired t-test indicated that plasma $\mathrm{CRH}, \mathrm{ACTH}$, and ALD levels decreased significantly in SHR group, In contrast, Ang II level in plasma increased markedly.

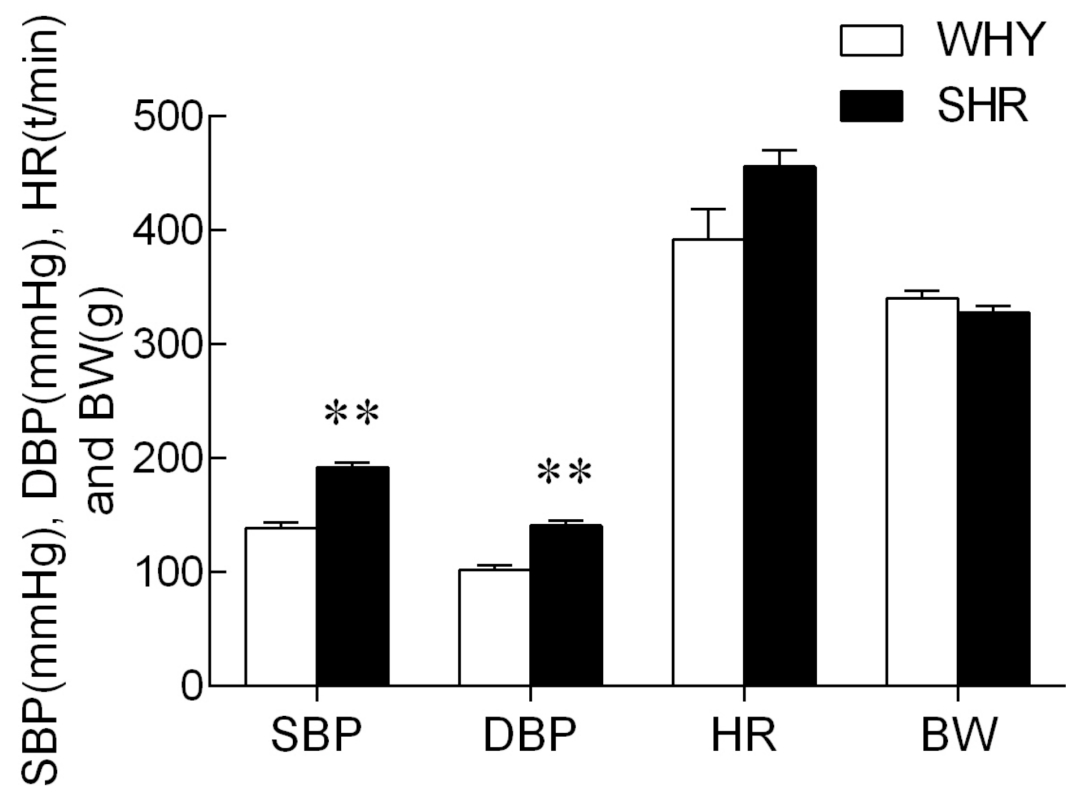

Figure 1: SBP, SDP, HR and BW of SHR compared with WKY.

Note: compared with WKY group, ${ }^{* *} \mathrm{P}<0.01$.

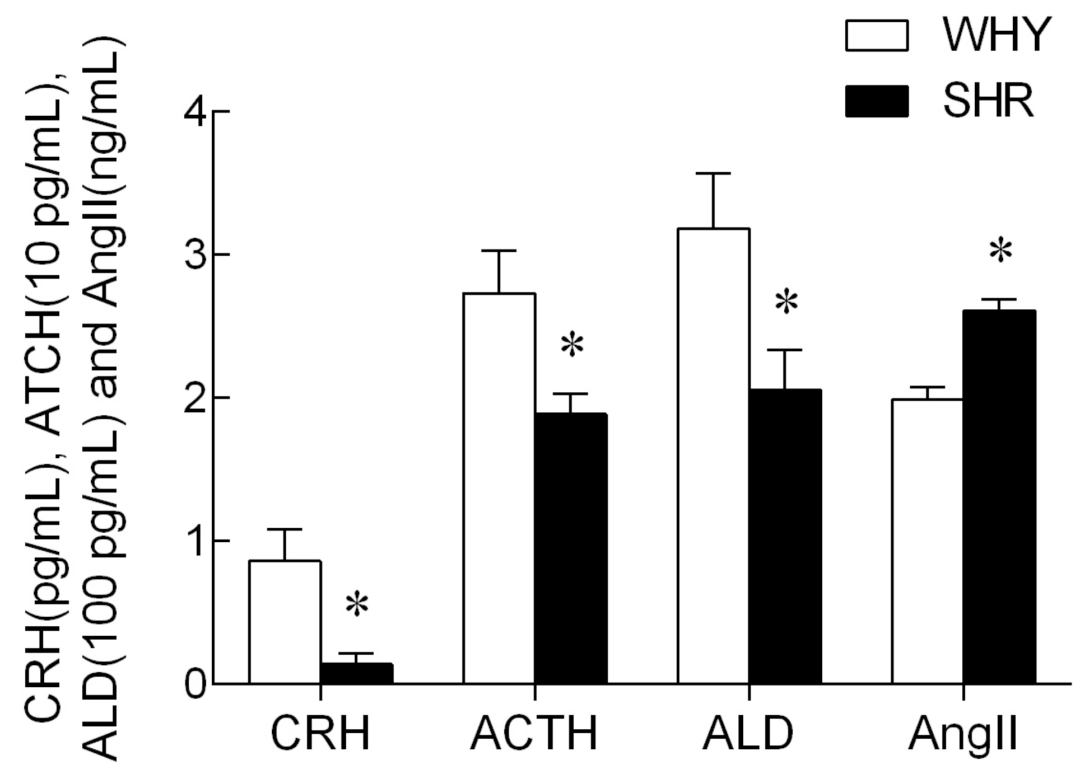

Figure 2: The content of CRH, ACTH, ALD and AngII in plasma from SHR compared with WKY. Note: compared with WKY, ${ }^{*} \mathrm{P}<0.05$. 


\section{RAS gene expression in hypothalamus and pituitary}

The expression of ACE, AT1R, ACE2 and MasR mRNA levels in the hypothalamus were illustrated in Figure 3A. Compared with the WKY group, the ACE mRNA levels of SHR were increased significantly, while the ACE2 mRNA levels showed a non-significant change between two groups. The AT1R and MasR mRNA were no observably changed. The expression of ACE, AT1R, ACE2 and MasR mRNA levels in the pituitary are illustrated in Figure 3B. Compared with the WKY group, the ACE, AT1R, ACE2, and MasR mRNA levels of SHR were not significantly changed.

The expression of TNF- $\alpha$, IL- $1 \beta$ and IL- 6 mRNA levels in the hypothalamus were illustrated in Figure 4.
Compared with the WKY group, the TNF- $\alpha$, IL- $1 \beta$ and IL-6 mRNA levels of SHR were increased significantly.

\section{ACE2 and ACE protein expression in hypothalamus}

To evaluate whether the decrease of ACE and ACE2 mRNA was associated with changes in protein, western blot was performed (Figure 5). Although the ACE2 mRNA in hypothalamus between two groups was not significantly altered, the ACE2 protein expression in SHR was significantly inhibited compared with that of WKY. The ACE protein expression in SHR was significantly higher than that of WKY. The sample proteins have been run under the same experimental conditions.
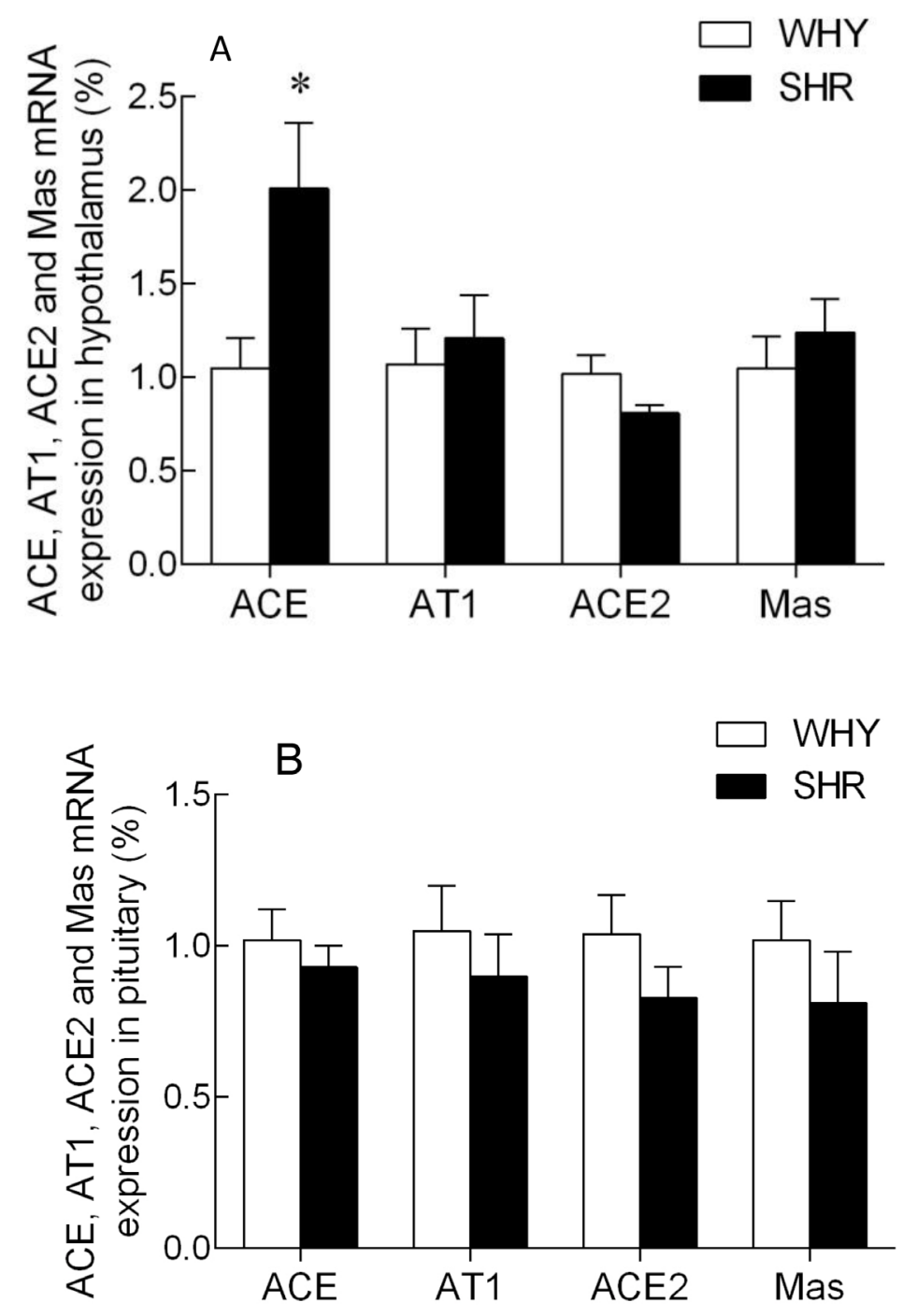

Figure 3: The expression of ACE, AT1R, ACE2 and MasR mRNA in hypothalamus and pituitary of SHR compared with WKY.

Note: A: the expression of ACE, AT1 ${ }_{\text {}}$ ACE2 and MasR mRNA in SHR hypothalamus compared with that of WKY group, * $\mathrm{P}<0.05$; B: the expression of ACE, $\mathrm{AT} 1_{\mathrm{B}}, \mathrm{ACE} 2$ and MasR mRNA in SHR pituitary compared with that of WKY group, ${ }^{*} \mathrm{P}<0.05$. 


\section{DISCUSSION}

The RAS is an attractive therapeutic target for management of cardiovascular disease [18]. Renin and ACE activity are used as biomarkers for disease states such as hypertension, diabetes, heart failure and renal diseases [19, 20, 21, 22]. However, recent data indicates that ACE2 has an opposing effect to that of ACE which could have novel implications regarding the role of RAS in hypertension and cardiovascular diseases [23, 24,
25]. Our data showed that ACE2 was expressed in both hypothalamus and pituitary of male WKY and SHR rats. The expression of RAS components has been documented in many tissues, such as heart, kidneys, pancreas, lung, adipose and brain [26, 27]. Previously, the ACE2 mRNA and protein were found to be expressed in forebrain, brainstem, subcortical organ (SFO), and ventrolateral medulla (VLM) of rat [28]. Also, ACE2 was expressed predominantly in the glial cells [4]. Although ACE2 expression has been reported in DOCA-salt hypertension

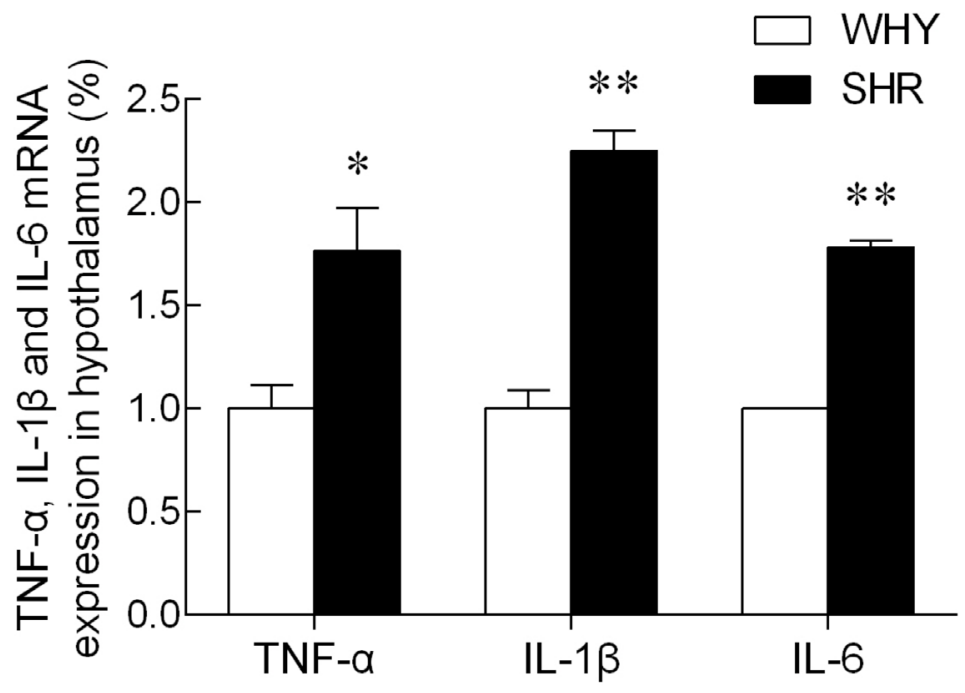

Figure 4: The expression of TNF- $\alpha$, IL-1 $\beta$ and IL-6 mRNA in hypothalamus.

Note: compared with WKY group, ${ }^{*} \mathrm{P}<0.05, * * \mathrm{P}<0.01$.

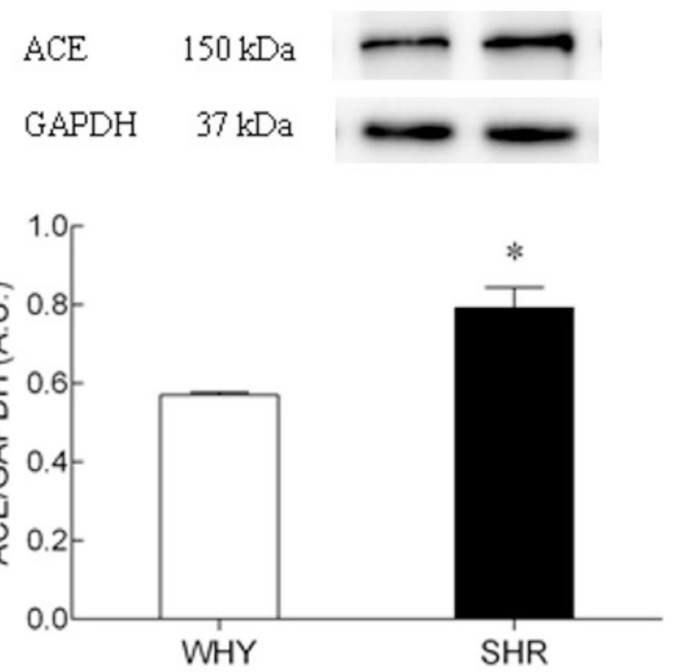

ACE2 $\quad 92 \mathrm{kDa}$

GAPDH

$37 \mathrm{kDa}$

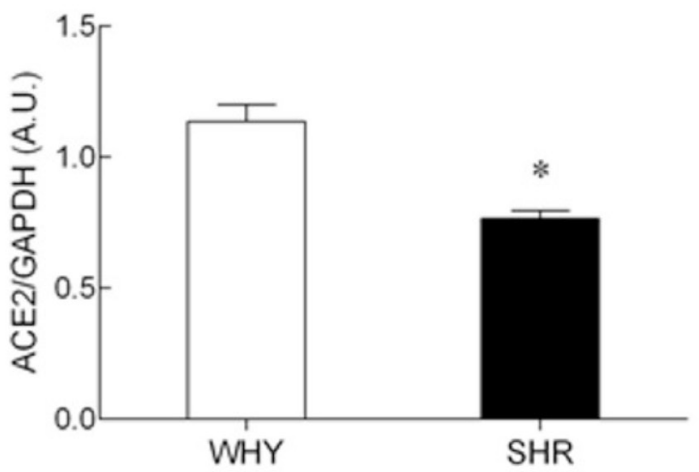

Figure 5: The protein expression of ACE2 on hypothalamus of SHR compared with WKY.

Lane 1: WKY group; Lane2: SHR group. The sample proteins have been run under the same experimental conditions, * $\mathrm{P}<0.05$. 
Table 1: Nucleotide Sequences of PCR Primers

\begin{tabular}{|c|c|c|c|c|}
\hline Gene & $\begin{array}{c}\text { GeneBank } \\
\text { Accession Number }\end{array}$ & Orientation & Primers Sequences (5'-3') & Product Size (bp) \\
\hline \multirow[t]{2}{*}{ ACE2 } & AY881244 & Forward & 5'-AATCGTAGGCTCTGGGCTTGG-3' & 182 \\
\hline & & Reverse & 5'-TTCGA TCAACTGGTTTCGGTTGTA-3' & \\
\hline \multirow[t]{2}{*}{ Mas } & NM012757 & Forward & 5'-TGACAGCCATCAGTGTGGAGA-3' & 116 \\
\hline & & Reverse & 5'-GCATGAAAGTGCCCACAGGA-3' & \\
\hline \multirow[t]{2}{*}{$\mathrm{ACE}$} & NM012544 & Forward & 5'-ATGCCTCTGCGTGGGACTTC-3' & 112 \\
\hline & & Reverse & 5'-TACTGCACGTGGCCCATCTC-3' & \\
\hline \multirow[t]{2}{*}{ AT1R } & NM030985 & Forward & 5'-CCCACTCAAGCCTGTCTACGAA-3' & 120 \\
\hline & & Reverse & 5'-GTGTGCTTTGAACCTGTCACTCC-3' & \\
\hline \multirow[t]{2}{*}{$\mathrm{TNF}-\alpha$} & NM013693 & Forward & 5'-GAGTGACAAGCCTGTAGCCC-3’ & 253 \\
\hline & & Reverse & 5'-GAGGTTGACTTTCTCCTGGTAT-3' & \\
\hline \multirow[t]{2}{*}{ IL-1 $\beta$} & NM031512 & Forward & 5'-GTGCGTGCTTAGATGTTGCT-3' & 265 \\
\hline & & Reverse & 5'-TGTTCCTACTTACCTTGTTGGC-3' & \\
\hline \multirow[t]{2}{*}{ IL-6 } & NM031168 & Forward & 5'-ATGGCAATTCTGATTGTATG-3' & 212 \\
\hline & & Reverse & 5'-GACTCTGGCTTTGTCTTTCT-3' & \\
\hline \multirow[t]{2}{*}{$\beta$-actin } & AF122902 & Forward & 5'-CCCTGTGCTGCTCACCGA-3' & 198 \\
\hline & & Reverse & 5'-ACAGTGTGGGTGACCCCGTC-3' & \\
\hline
\end{tabular}

mice [17, 29], its expression in the hypothalamus and pituitary of SHR is unknown. Therefore, our goal was to study the expression of ACE2 in the hypothalamuspituitary axis of rat and its relationship with hypertension.

Our study demonstrated that ACE, AT1R, ACE2, MasR mRNA were expressed in the hypothalamus and pituitary of both, the WKY and SHR rats. The upregulation of ACE mRNA and the downregulation of ACE2 mRNA and protein in hypothalamus suggested that the balance between hypothalamic ACE2 and ACE determined blood pressure. The RAS in the nervous system is critical for regulating hypertension and cardiovascular diseases. The expression of ACE2 is suppressed in RVLM of SHR compared to WKY, whereas overexpression of ACE2 decreased the high blood pressure in SHR [30]. In addition, ACE2 overexpression in the PVN demonstrated beneficial effects against the Ang II-induced hypertensive response [10]. However, similar expression of ACE, AT1R, ACE2, MasR mRNA in the pituitary of both groups of mice indicated that the pituitary RAS was not involved in the hypertension demonstrated by SHR rats.

The higher plasma levels of AngII in the SHR compared to WKY showed that the ACE-AngII-AT1R axis was hyperactive in the hypothalamus of SHR where theACE2 protein was insufficient. ACE is a key factor of RAS and generates AngII that promotes the secretion of vasopressin that causes vasoconstriction [31]. In addition, Ang (1-7), a product of ACE2, which inhibits AngII, was highly expressed in medulla oblongata and hypothalamus [32]. Elevated AngII levels induced inflammation [33], whereas overexpression of ACE2 reduced local inflammation in the hypothalamus [10]. In this context, we observed that the mRNA levels of TNF- $\alpha$, IL-1 $\beta$ and IL-6 were enhanced in SHR compared to WKY in the hypothalamus.

ACTH increases blood pressure by inducing the release of glucocorticoids and probably aldosterone from the adrenal cortex into circulation [34]. In this study, we observed that the levels of CRH, ACTH, and ALD in the plasma were lower in SHR rats compared to WKY $(\mathrm{P}<0.05)$, suggesting that the activity of the HPA axis was reduced in chronic hypertension.

In summary, our data suggested that the ACE-AngIIAT1R axis was hyperactive in the hypothalamus RAS of SHR where the ACE2 protein was relatively insufficient and the pituitary was not involved in the hypertension of SHR rats.

\section{MATERIALS AND METHODS}

\section{Animals}

All animal experiments were performed in accordance with relevant guidelines and regulations of the Institutional Ethical Committee of Nanjing Agricultural University Institutional Animal Care and Use. All animal 
experimental protocols were approved by Institutional Ethical Committee of Nanjing Agricultural University. Fourteen week old male SHR $(n=8)$ and WKY rats $(n=8)$ from Shanghai Experimental Animal Center (Shanghai, China) were housed in individual cages with free access to water and rat chow ( Xie-tong Medicine Biological Engineering Co., Ltd., Jiangsu, China) for one week. Then all rats were euthanized by cervical dislocation and trunk blood samples collected. Hypothalamus and pituitaries were collected and frozen at $-80^{\circ} \mathrm{C}$.

\section{Blood pressure, heart rate, and body weights}

The rat systolic blood pressure (SBP), diastolic blood pressure (SDP) and heart rate (HR) was measured using a multi-channel noninvasive pressure system under a conscious resting state. The body weight was measured with a weighing-machine.

\section{Plasma radioimmunoassay}

Plasma CRH, ACTH, ALD, and Ang II levels were determined with commercially available radioimmunoassay kits of $\mathrm{CRH}, \mathrm{ACTH}, \mathrm{ALD}$ and Ang II (Beifang BioTech Co. Ltd, Beijing, China) according to the manufacturer's protocol. The radioactive precipitation was counted by a $\gamma$-counter. The intra- and inter-assay coefficients of variation were less than $10 \%$ and $15 \%$.

\section{Real-time quantitative PCR assay}

RNA was extracted from the hypothalamus and pituitary using an RNeasy mini kit (Tiangen). The cDNA was generated by using PrimeScript RT reagent Kit (TaKaRa) with oligo-dT and random primer. The realtime PCR reaction was then performed in an ABI Prism 7700 Detection System (ABI, USA). The sequences of rat ACE, ACE2, AT1R, MasR, TNF- $\alpha$, IL-1 $\beta$, IL-6 and $\beta$-actin primers were listed in Table 1. Message levels were normalized to $\beta$-actin levels in each experiment.

\section{Western blot analysis}

Tissue was homogenized in RIPA lysis buffer containing protease inhibitor mixture [18]. Protein concentration was determined with BCA Protein Assay Kit (Beyotime Institute of Biotechnology, Shanghai, China). Normalized amount of sample proteins $(60 \mu \mathrm{g} / \mathrm{lane})$ were separated by $8 \%$ SDS-PAGE gel and transferred to PVDF membrane with a Pegasus semi-dry-blotter (Bio-rad, USA). After blocking in 5\% skim milk in TBS with $0.1 \%$ tween-20 (TBST) at room temperature, the membrane was incubated with diluted primary antibody against ACE2 (1:400, Santa Cruz Biotechnology Inc, USA) or ACE (1:1000, Abcam, USA) over night at $4^{\circ} \mathrm{C}$. After being washed four times with TBST, the membrane was incubated with HRP-conjugated anti-rabbit IgG (1:10000, Boster Biological Technology,
Ltd, Wuhan) for $1 \mathrm{~h}$ at room temperature. After being washed with TBST, specific immunoreactive proteins were detected by enhanced ECL substrate (Beyotime Institute of Biotechnology, Shanghai, China) on a chemiluminescence system (Tanon, Shanghai, China).

\section{Statistical analysis}

Data were analyzed by t-test using SPSS version 17.0. Each value was expressed as mean \pm standard error (SE). Statistical significance was accepted for $\mathrm{P}<0.05$.

\section{ACKNOWLEDGMENTS}

This work was supported by a grant (30871838) from National Natural Science Foundation of China, Priority Academic Program Development of Jiangsu Higher Education Institutions (PAPD)

\section{CONFLICTS OF INTEREST}

The authors declare that there is no conflicts of interest.

\section{Authors' contributions}

Yuanshu Zhang and Kun Wang designed the study. Kun Wang, Yuanyuan Xu and Weiwei Yang performed the experiments. Kun Wang performed the analysis. Kun Wang wrote the manuscript. Yuanshu Zhang and Kun Wang edited and revised the manuscript.

\section{REFERENCES}

1. Turner AJ, Hooper NM. The angiotensin-converting enzyme gene family: genomics and pharmacology. Trends Pharmacol Sci. 2002; 23:177-183.

2. Donoghue M, Hsieh F, Baronas E, Godbout K, Gosselin M, Stagliano N, Donovan M, Woolf B, Robison K, Jeyaseelan $\mathrm{R}$, Breitbart RE, Acton S. A novel angiotensin-converting enzyme-related carboxypeptidase (ACE2) converts angiotensin I to angiotensin 1-9. Circ Res. 2000; 87:E1-E9.

3. Tipnis SR, Hooper NM, Hyde R, Karran E, Christie G, Turner AJ. A human homolog of angiotensin-converting enzyme. Cloning and functional expression as a captoprilinsensitive carboxypeptidase. J Biol Chem. 2000; 275:33238-33243.

4. Gallagher PE, Chappell MC, Ferrario CM, Tallant EA. Distinct roles for ANG II and ANG-(1-7) in the regulation of angiotensin-converting enzyme 2 in rat astrocytes. Am J Physiol Cell Physiol. 2006; 290:C420-C426.

5. Santos RA, Ferreira AJ, Verano-Braga T, Bader M. Angiotensin-converting enzyme 2, angiotensin-(1-7) and Mas: new players of the renin-angiotensin system. J Endocrinol. 2013; 216:R1-R17. 
6. Ferrario CM, Jessup J, Gallagher PE, Averill DB, Brosnihan KB, Ann Tallant E, Smith RD, Chappell MC. Effects of renin-angiotensin system blockade on renal angiotensin-(1-7) forming enzymes and receptors. Kidney Int. $2005 ; 68: 2189-2196$.

7. Jöhren $\mathrm{O}$, Golsch C, Dendorfer A, Qadri F, Häuser W, Dominiak P. Differential Expression of AT1 Receptors in the Pituitary and Adrenal Gland of SHR and WKY. Hypertension. 2003; 41:984-990.

8. Yang Z, Yu X, Cheng L, Miao LY, Li HX, Han LH, Jiang WP. Effects of enalapril on the expression of cardiac angiotensin-converting enzyme and angiotensin-converting enzyme 2 in spontaneously hypertensive rats. Arch Cardiovasc Dis. 2013; 106:196-201.

9. Lu Y, Chen J, Yin X, Zhao H. Angiotensin II receptor 1 involved in the central pressor response induced by interleukin-1 beta in the paraventricular nucleus. Neurol Res 2009; 31:420-424.

10. Sriramula S, Cardinale JP, Lazartigues E, Francis J. ACE2 overexpression in the paraventricular nucleus attenuates angiotensin II-induced hypertension. Cardiovasc Res. 2011; 92:401-408.

11. Paul M, Poyan MA, Kreutz R. Physiology of local reninangiotensin systems. Physiol Rev. 2006; 86:747-803.

12. McKinley MJ, Albiston AL, Allen AM, Mathai ML, May CN, McAllen RM, Oldfield BJ, Mendelsohn FA, Chai SY. The brain renin-angiotensin system: location and physiological roles. Int J Biochem Cell Biol. 2003; 35:901-918.

13. Phillips MI, Sumners C. Angiotensin II in central nervous system physiology. Regul Pept. 1998; 78:1-11.

14. Phillips MI, Oliveira EM. Brain renin angiotensin in disease. J Mol Med (Berl). 2008; 86:715-722.

15. Lin Z, Chen Y, Zhang W, Chen AF, Lin S, Morris M. RNA interference shows interactions between mouse brainstem angiotensin AT1 receptors and angiotensin-converting enzyme 2. Exp Physiol. 2008; 93:676-684.

16. Sriramula S, Xia H, Xu P, Lazartigues E. Brain-Targeted Angiotensin-Converting Enzyme 2 Overexpression Attenuates Neurogenic Hypertension by Inhibiting Cyclooxygenase-Mediated Inflammation. Hypertension. 2015; 65:577-586.

17. Xia H, de Queiroz TM, Sriramula S, Feng Y, Johnson T, Mungrue IN, Lazartigues E. Brain ACE2 overexpression reduces DOCA-salt hypertension independently of endoplasmic reticulum stress. Am J Physiol Regul Integr Comp Physiol. 2015; 308:R370-R378.

18. Ferreira, AJ, Santos, RA, Bradford, CN, Mecca, AP, Sumners, C, Katovich, MJ, Raizada, MK. Therapeutic implications of the vasoprotective axis of the reninangiotensin system in cardiovascular diseases. Hypertension. 2010; 55:207-213.

19. Jeunemaitre X, Lifton RP, Hunt SC, Williams RR, Lalouel $\mathrm{JM}$. Absence of linkage between the angiotensin converting enzyme locus and human essential hypertension. Nat Genet. 1992; 1:72-75.

20. Park S, Bivona BJ, Kobori H, Seth DM, Chappell MC, Lazartigues E, Harrison-Bernard LM. Major role for ACEindependent intrarenal ANG II formation in type II diabetes. Am J Physiol Renal Physiol. 2010; 298:F37-F48.

21. Jorde UP, Ennezat PV, Lisker J, Suryadevara V, Infeld J, Cukon S, Hammer A, Sonnenblick EH, Le Jemtel TH. Maximally recommended doses of angiotensin-converting enzyme (ACE) inhibitors do not completely prevent ACEmediated formation of angiotensin II in chronic heart failure. Circulation. 2000; 101:844-846.

22. Iwai M, Horiuchi $M$. Devil and angel in the reninangiotensin system: ACE-angiotensin II-AT1 receptor axis vs. ACE2-angiotensin-(1-7)-Mas receptor axis. Hypertens Res. 2009; 32:533-536.

23. Hampl V, Herget J, Bíbová J, Baňasová A, Husková Z, Vaňourková Z, Jíchová Š, Kujal P, Vernerová Z, Sadowski J, Červenka L. Intrapulmonary activation of the angiotensinconverting enzyme type 2/angiotensin 1-7/G-proteincoupled Mas receptor axis attenuates pulmonary hypertension in Ren-2 transgenic rats exposed to chronic hypoxia. Physiol Res. 2015; 64:25-38.

24. Wang W, Patel VB, Parajuli N, Fan D, Basu R, Wang Z, Ramprasath T, Kassiri Z, Penninger JM, Oudit GY. Heterozygote loss of ACE2 is sufficient to increase the susceptibility to heart disease. J Mol Med (Berl). 2014; 92:847-858.

25. Patel SK, Velkoska E, Freeman M, Wai B, Lancefield TF, Burrell LM. From gene to protein-experimental and clinical studies of ACE2 in blood pressure control and arterial hypertension. Front Physiol. 2014; 5:227.

26. Cheung WJ, Kent MA, El-Shahat E, Wang H, Tan J, White R, Leenen FH. Central and peripheral renin-angiotensin systems in ouabain-induced hypertension. Am J Physiol Heart Circ Physiol. 2006; 291:H624-H630.

27. Ptasińska-Wnuk D, Lawnicka H, Fryczak J, KunertRadek J, Pawlikowski M. Angiotensin peptides regulate angiogenic activity in rat anterior pituitary tumour cell cultures. Endokrynol Pol. 2007; 58:478-486.

28. Doobay MF, Talman LS, Obr TD, Tian X, Davisson RL, Lazartigues E. Differential expression of neuronal ACE2 in transgenic mice with overexpression of the brain reninangiotensin system. Am J Physiol Regul Integr Comp Physiol. 2007; 292:R373-R381.

29. Xia H, Sriramula S, Chhabra KH, Lazartigues E. Brain angiotensin-converting enzyme type 2 shedding contributes to the development of neurogenic hypertension. Circ Res. 2013;113:1087-1096.

30. Yamazato M, Yamazato Y, Sun C, Diez-Freire C, Raizada MK. Overexpression of angiotensin-converting enzyme 2 in the rostral ventrolateral medulla causes long-term decrease in blood pressure in the spontaneously hypertensive rats. Hypertension. 2007; 49:926-931. 
31. Zhao X, White R, Huang BS, Van Huysse J, Leenen FH. High salt intake and the brain renin — angiotensin system in Dahl salt-sensitive rats. J Hypertens. 2001; 19:89-98.

32. Höcht C, Gironacci MM, Mayer MA, Schuman M, Bertera FM, Taira CA. Involvement of angiotensin-(1-7) in the hypothalamic hypotensive effect of captopril in sinoaortic denervated rats. Regul Pept. 2008; 146:58-66.
33. Oudit GY, Kassiri Z, Patel MP, Chappell M, Butany J, Backx PH, Tsushima RG, Scholey JW, Khokha R, Penninger JM. Angiotensin II-mediated oxidative stress and inflammation mediate the age-dependent cardiomyopathy in ACE2 null mice. Cardiovasc Res. 2007; 75:29-39.

34. Lumbers ER. Angiotensin and aldosterone. Regulatory Peptides, 1999, 80:91-100. 